
1953-61 ${ }^{1}$

Assessments of the CIA's role in Latin America during the 1950s have tended to focus predominantly on the twin case-studies of Guatemala and Cuba. Consequently, the Agency's role - and, more broadly, that of its head Allen Dulles - has come to be seen as one obsessed with covert action and relatively unimportant in terms of policy discussions. Dulles, in fact, has been portrayed as an unwilling and disinterested participant in policy discussions. The present article will challenge those assertions by suggesting that, by examining Dulles's role in the Eisenhower administration's discussions on Latin America, a different picture emerges - one that paints Dulles as an active and rational participant, and which raises important questions for our understanding of the CIA's role during the Eisenhower era. 
'In the 1950s', writes Greg Grandin in describing the Central Intelligence Agency's role in Guatemala in 1954, 'the Cold War was often presented as a battle of ideas, yet CIA agents on the ground didn't see it that way'...they insisted 'on a strategy intended to inspire fear more than virtue.' Grandin's view - along with the widely held perception among many nonspecialists that the 1950s served as a form of 'golden age' for the CIA - has come to dominate historical, and indeed cultural, representations of the Agency's role in the earlyCold War era. During the period when Dwight D. Eisenhower was president and Allen Dulles was the Director of Central Intelligence (DCI), it is commonly held, the CIA enjoyed a position of unparalleled success in US foreign policy. Obviously, this has been a 'golden age' with significant caveats: while the Agency may have enjoyed significant prominence in the implementation of US policy in this era, it is not seen as being a key player in terms of policy making. Its record of operations, meanwhile, has been strongly criticised by scholars concerned at the way that the Cold War served to legitimise operations that had disastrous consequences in human terms. ${ }^{3}$

Nonetheless, revelations about the CIA's activities in this period - particularly with respect to the Third World, where CIA interventions were most flagrant and most damaging have only served to strengthen this perception of Agency influence. With Eisenhower's proclivity toward psychological warfare and covert operations increasingly to the fore, the CIA was an essential part of his armoury in the ongoing struggle against the Soviet Union. ${ }^{4}$ Predictably, Allen Dulles has become synonymous with this period: the DCI who pursued the Agency's interests, oversaw its interventions and did his president's bidding. Shortly after his death in 1969, for example, Time demonstrated the enduring power of the Allen Dulles-CIA link. 'At the austere CIA headquarters' at Langley - constructed almost as monument to the Dulles era - 'a bas-relief plaque with Allen Dulles' likeness bears the inscription: "His Monument Is Around Us". 5 To be sure, this has often been to his detriment. Allen Dulles may have been a key protagonist in building the Cold War CIA, but his tenure also oversaw a series of disastrous and illegal interventions. Dulles's Agency broke international law, subverted democratically elected governments and supported brutal dictatorships as long as they were pro-American - all under a banner of legitimisation provided by the Cold War.

This legacy has been especially prevalent in the Americas. As a test of this, it is worth considering what comes to mind when mentioning the phrase the 'CIA in Latin America in the 1950s.' For most of us, it is inevitably two case studies: Guatemala and Cuba. The CIA's role in planning for covert operations in these two nations - one a "success" in Guatemala in 1954, the other a precursor to a disaster in Cuba in 1961 - have come to be seen as the predominant examples of the Agency's role in Eisenhower's Latin American policy. In historiographical terms, this has had two major outcomes. First, it has contributed significantly to the predominant school of thought regarding Allen Dulles - which paints him as an excitable and adventurous advocate and planner of covert operations, but as a disinterested and unwilling participant in wider policy discussions. ${ }^{6}$ Second, it has helped to confirm the view that the CIA's role in inter-American affairs at this time was primarily as an operational and intelligence gathering body. (Studies of Eisenhower's Latin American policy, 
it bears noting, do not often mention the CIA apart from its involvement in Guatemala and Cuba). ${ }^{7}$ Consequently, Dulles has become rarely featured in examinations of US policy discussions on Latin America.

By contrast, the present article will argue that, when it came to policy discussions over Latin America, Allen Dulles was far from the disinterested and unwilling participant he is often portrayed as. Rather, he was a well-informed and pragmatic advisor who challenged the assertions of other administration officials, notably his brother, secretary of state John Foster Dulles, and vice president Richard Nixon, and who refused to adopt simplistic or reflexive notions of blaming communists for every problem encountered in the region. This is not to suggest that Dulles was soft on communism and the Soviet Union, that he did not have his own motives in mind, or an attempt to revise past critical judgements. After all, he could be as strident and as forthright on such topics as any of Eisenhower's advisors, while his failings and foibles have been well documented and accurately depicted. Instead, it is to contend that Dulles's approach in internal policy discussions was often based on pragmatic assessments of the available data. And while he would often stop short of outright policy suggestions - believing these to be outside the remit of his role - he would frequently seek to ensure that decisions were taken that would stand up to scrutiny. Of course, some of this was to ensure that the Agency's reputation remained intact: Dulles was determined that the Agency was successful, and that its clinical achievements in operational affairs were matched by reliability and rationality in terms of intelligence. But the fact that this facet to his personality remained constant throughout Eisenhower's presidency also suggests a clear modus operandi that is clearly at odds with the way he was portrayed, both at the time and in later examinations.

In practical terms, then, Allen Dulles was one of Eisenhower's most rational advisors on Latin American political affairs. Interestingly, this rarely brought about a dramatic change in approach or policy; yet it does provide a new angle on the role played by Dulles - and, more broadly, the CIA - in the administration's discussions toward the region. Whether this reappraisal is one that repeats itself with regard to other areas of the world, however, remains to be seen. Nevertheless, Dulles's continually pragmatic contributions to administration discussions over Latin America need to be considered in isolation from the Agency's broader reputation - firstly, to understand Allen Dulles's role more fully, and secondly, to broaden our conception of the administration's policy-making dynamic in certain areas.

\section{DULLES AND INTELLIGENCE}

Dulles himself has provoked some of the prevailing historical conclusions that have characterised his role. In The Craft of Intelligence Dulles often refers to the National Security Act of 1947 as being the blueprint for the role of the CIA and the DCI. ${ }^{8}$ The act is clear about the way that intelligence information should be presented. 'The Director of National Intelligence,' should provide intelligence that is 'timely, objective, independent of political considerations, and based upon all sources available to the intelligence community. ${ }^{9}$ While 
Dulles's account seems predictably self-serving - working to absolve him of any criticism for getting involved in policy-making - it also downplays his participation in policy discussions. His description of what constituted an 'ideal spy' in a collection of spy stories that he edited in 1968, furthermore, reinforced the emphasis on Dulles's role as daring super-agent focused predominantly on operational duties. 'Greatness as a human being and greatness in the accomplishment of his mission,' Dulles wrote, were the qualities needed to make a great spy. ${ }^{10}$

Dulles scholars, therefore, have tended to focus on this aspect of Dulles's personality. Peter Grose, for example, has argued that 'Allen, for his part, was nurtured in matters of foreign policy, but he always claimed that his duty was only that of a professional intelligence officer, leaving the policymaking to others.' Richard Immerman has made a similar argument, suggesting that Dulles 'would rather overthrow a government than evaluate it.' In an overly positive biography of Dulles, James Srodes makes the nonetheless important point that he was 'a complex personality' - shunning 'the front rank of history' but hungering 'for power and the accompanying celebrity' - imbued with a 'sense of moral certainty' and a 'reputation for incisive honesty.' Hugh Wilford's appraisal is closer to the mark, describing Dulles as being ideally suited to the role of a spy due to his 'jovial pragmatism and inner coldness'. By contrast, Tim Weiner has provided one of the most caricatured appraisals of Dulles: 'through his devotion to covert action, his disdain for the details of analysis, and his dangerous practice of deceiving the president of the United States, Allen Dulles did untold damage to the agency he had helped to create. ${ }^{11}$ To be sure, these were key facets of his personality; Dulles enjoyed the cut-and-thrust of intelligence operations, and did have a playful aspect to his character. In 1957, for instance, he and former Treasury Secretary George Humphrey initiated a wager as to whether Egyptian leader, Gamal Abdel Nasser, would be out of office within six months. ${ }^{12}$ The majority of historical analysis, then, has focused on Dulles's role in covert operations and as head of the CIA rather than policymaking discussions. Selected quotes and episodes are included, but there are few concerted efforts to analyse Dulles's position in internal policy matters. Another reason for this, it should be noted, is that available archival materials on Dulles remain far from complete. Many sources relating to his activities remain unopened, while even those that are available are far from voluminous. To cite an oft-quoted example of the this, historians know that the Dulles brothers met up most weekends to discuss policy issues but have very little idea of what they said to each other. Indeed, the entire relationship between the Dulles brothers - and the way this played out in policy-making circles - is often a matter of little more than speculation. ${ }^{13}$ In the midst of an incomplete historical record, new analyses of Dulles and the Agency remain subject to qualifications.

Nevertheless, it is easy to see where this emphasis on Dulles's role in operations has come from. The CIA's legacy under his leadership was most obviously felt in the field of operations - with a series of ostensibly successful interventions undertaken which often had tragic outcomes for the nations involved. ${ }^{14}$ Moreover, his background in intelligence before joining the fledgling CIA was that of an operative keenly embracing operational responsibility and enjoying the cut-and-thrust of covert action. In both world wars Dulles was 
an intelligence operative in Switzerland. Following World War Two, he was involved in the formative stages of the CIA - culminating, in the early-1950s, with a senior operational role and, in 1953, with a move to become the Director of Central Intelligence. By 1953, moreover, the CIA had emerged as a powerful and stable institution within the Washington bureaucracy. Dulles was head of an Agency that was both important and well funded; its reach was extensive and it was subject to little congressional oversight. ${ }^{15}$

For Eisenhower and John Foster Dulles, of course, the desirability of having the secretary of state's brother in charge of the CIA came from the certainty that he would very much serve as their man in the Agency, ensuring that it was used as an effective operational arm for an administration concerned as much with financial prudence as waging the Cold War. ${ }^{16}$ Yet he also began to demonstrate a candour and pragmatism in analysis and discussion that is somewhat removed from the archetypal view of his role. This was not always matched by his tone in private, which was often more bellicose and less guarded then it was in official settings, but its recurrent nature under Eisenhower had an undoubted impact on the administration's decisions. Perhaps most significantly, Dulles demonstrated a willingness in his understanding of the global situation to move beyond traditional constructs regarding a communist 'monolith'. ${ }^{17}$ In a speech at the National War College in 1954, for instance, Dulles provided an analysis of Soviet policy that was somewhat removed from the dogmatic monolith of popular conception. 'When we come to deal with the question of Soviet policy, or the policy, for that matter, of any country in the world,' he stated, 'I think we make a great mistake if we assume there is any clear-cut blueprint...I believe that the Soviet leaders improvise in many phases of their policy as events unroll, just as we have to do, and have their uncalculated reverses just as we do., 18

Dulles also demonstrated a capacity to starkly criticize US policy if he believed that the Soviets had stolen a march due to American mistakes. This became especially evident in the mid-1950s - when Moscow moved purposefully to court the "hearts and minds" of the Third World through diplomatic overtures and offers of economic assistance, and when the US was compelled to face up to a growing Soviet challenge in the developing world. ${ }^{19}$ In many areas of the developing world - but particularly in Southeast Asia and the Middle East - the Soviet Union was able to make swift progress in its attempts to curry favour with socalled neutral nations by offering deals that the US would never have agreed to. For Dulles, Moscow's efforts demonstrated a realistic appraisal of the nature of economic development in those regions. In an undated report from 1956 Dulles noted, 'they [the Soviets] have created the impression that they do not look upon,' the peoples of South and Southeast Asia and the Middle East 'as "backward" or "underdeveloped", phrases we have too often used.' Furthermore, he went on, 'the Soviets have been most flexible...they have required no obvious quid pro quo in their negotiations. ${ }^{20}$

His ruminations on this point, moreover, led him to some important conclusions about the inherent difficulties that the US faced in adhering to its own model of development in the face of Soviet incursions, particularly in an area like Asia which was suffering from chronic under-development. 'Regrettable as it might be,' he told the NSC meeting of 18 January, 
1956, 'most of the free countries of Asia have such primitive societies and governments that there is no private enterprise which can be developed and supported by US assistance programs. ${ }^{21} \mathrm{He}$ was also acutely aware of emerging threats to American interests. In Eisenhower's second term - when US appraisals and conceptions of the non-aligned nations were gradually becoming more sophisticated - Dulles provided a succinct appraisal of how events among the Third World could affect US objectives. In these circumstances, Dulles explained, overt Soviet action was easier to deal with and less damaging than a show of dissent from a nation that the US was trying to court. 'Soviet aggression through recourse to limited wars,' Dulles stated, 'presented the United States with much less of a problem than was presented by developments such as those in Indonesia, which the Soviets could effectively exploit to weaken the Free World. ${ }^{22}$

There is also a sense, Dulles's disavowals regarding the proper role of the DCI notwithstanding, that Eisenhower increasingly saw Dulles as much more than just a provider of intelligence. In December 1953, in an end of year letter to the DCI, Eisenhower enthused about Dulles's role in 'assuring that our common purpose of sustaining maximum individual freedom and responsibility is not only woven better into the laws of the land, but there will be no deviation from the goal of helping every American to achieve constantly rising standards of health, education, and prosperity. ${ }^{23}$ In 1957, as the Killian Committee got ready to make its recommendations on US technology in the wake of the successful Soviet launch of Sputnik, Dulles wrote to Eisenhower and informed him that he was 'looking forward to discussing their conclusions with you'. ${ }^{24}$ By 1960, meanwhile, Eisenhower was thanking Dulles for his 'counsel, assistance and [his] very presence'. ${ }^{25}$ Collectively, the above examples suggest that the DCI was much more within the administration than just a supplier of intelligence.

As this tour d'horizon of some of Allen Dulles's contributions to Eisenhower administration policy discussions suggests, he often took positions that were rational and perceptive, somewhat bucking the perception of him as a disinterested participant in policy discussions. To be sure, he was not opposed to rhetorical cheerleading or attempts to gee up foreign allies. He speculatively told British officials in Geneva in 1956 that, 'according to his intelligence the Communists were in some difficulty in North Vietnam and were not doing too well even in Laos. ${ }^{26}$ But in internal discussions he rarely adopted such assertive positions. In keeping with his understanding of the National Security Act, the available evidence suggests that he rarely made overt policy demands. Nonetheless, his opinion carried significant weight. It is worth noting here that Allen Dulles was not always a contrarian voice: oftentimes, he was supporting positions already taken and further elucidating existing propositions. On other occasions - when CIA interests were not at stake or he did not feel the need to interpose his own view - Dulles did not involve himself. The constant aspect to this, however, was Dulles's pragmatic tone when he did speak up - a tone that was particularly evident in his involvement on discussions over the administration's policy toward Latin America. 


\section{ALLEN DULLES AND LATIN AMERICA DURING EISENHOWER'S FIRST TERM}

Dulles's first involvement on Latin American affairs in 1953 typified the way that he would participate in discussions of the administration's regional policy. At the NSC Meeting on 18 February, Dulles offered a summary of the situation in the region that was multifaceted, sobering and complex. Some problems, he noted, were undoubtedly caused by communist groups - although not Moscow itself - but other difficulties were motivated by different factors. 'The four major trends in South and Central America were trends in the direction of economic nationalism, regionalism, neutralism, and increasing Communist influence.' Each of these, he continued, posed an equal threat to US interests. ${ }^{27}$ This summary was at odds with that which would characterize wider statements of other US officials; in testimonies to Congress, John Foster Dulles starkly invoked the communist menace in the region. ${ }^{28}$ While this was, predictably, motivated by the desire to secure a consensus for US policies in the region, Allen Dulles's breakdown of the differing elements in the region was the most sophisticated appraisal put forward by one of Eisenhower's leading advisors. Toward the end of the same meeting, DCI Dulles outlined his resistance to becoming involved in substantive policy discussions. After Eisenhower asked him 'what could be done to improve the situation in South America,' Dulles replied: 'while it was not within his province to deal with policy, it was at least clear to him that this Government needed to review the situation in Latin America. ${ }^{29}$

In the discussions which followed and led up to the creation of the administration's first regional policy document, neither Dulles nor the CIA played much of a role beyond the imparting of intelligence data. ${ }^{30}$ At the March 18 NSC meeting to finalise the document Allen Dulles's voice was not heard. ${ }^{31}$ And while his appraisal of the different challenges confronting the administration in the region was evident in the document's final draft, this was clearly a policy driven by Eisenhower, Foster Dulles, and the appropriate officials from the departments of State, Defense and Treasury. ${ }^{32}$ Subsequent progress reports on the development of the inter-American relationship - while taking into account information 'furnished' by the Agency - included little reference to CIA activities or a role in policy implementation. Even in the fields of 'information' and 'public relations' there was little mention of a CIA role, with much of the efforts being undertaken by organisations like the USIA or through high-profile gestures such as the president's speech before the Organization of American States (OAS). ${ }^{33}$

Dulles and the CIA became much more prominent in those cases considered to be of pressing strategic importance. During Eisenhower's first term the most high-profile - and infamous - of these was the developing situation in Guatemala, where the elected government of Jacobo Arbenz was causing increasing concern to the US due to its alternative socio-economic agenda and rumoured links to regional and international communist groups. ${ }^{34}$ Discussions about a possible intervention had been ongoing since 1950, when fears about potential links between the Guatemalan government and local and international communists began to gather pace. The presence of high-profile Guatemalan communists in the governments of Jose Arévalo and Jacobo Arbenz, coupled with economic and agricultural 
policies that eventually led to the appropriation of land from the United Fruit Company in 1953, provided the catalyst for serious consideration of a covert operation to help Guatemalan dissidents overthrow the incumbent regime. Though these discussions ultimately came to naught - with poor security at the CIA and State Department indecision undermining early plans - the situation remained in need of resolution when Eisenhower entered the White House. $^{35}$

At the aforementioned NSC meeting of 18 February, 1953, Dulles had highlighted the Guatemalan situation as the most pressing threat to American interests in the region, as 'the development of pro-Communist influence was such as to mark an approaching crisis. It was quite possible,' he continued, 'that Guatemala's neighbours might take military action to protect themselves from Communist infection. ${ }^{36}$ Dulles's use of the term 'communist infection' was deliberate and suggestive; like many of his contemporaries in the administration, he was well aware that its use heightened tensions and increased the likelihood of action being taken. Such sentiments, moreover, fit his private assessment detailed in a CIA memorandum for the record where he wrote: 'They [the Guatemalans] have flaunted us and consistently got away with it. It is time they were brought to realize that this could not continue.' In this memo he went on to raise the possibility of the president warning of Soviet penetration of Guatemala and of the administration sponsoring two congressmen to make speeches along similar lines - suggestions which he would likely have steered clear of in policy discussions among the NSC. ${ }^{37}$ Nevertheless, Dulles was not the only person expressing such views about the challenge that Guatemala posed to US interests, and in a National Intelligence Estimate produced shortly after Dulles's memorandum the DCI's influence can be clearly seen. 'Guatemala,' the report argued, 'has frequently taken occasion to demonstrate its independence of US leadership and in general has been less cooperative than could be desired. ${ }^{38}$ As planning continued and the US ramped up its rhetoric regarding the challenge facing it in Guatemala the prospects of intervention became ever more likely. ${ }^{39}$

In terms of operational planning and implementation, the Agency quickly became the central player. But the actual impetus for intervention came from the president. As Nick Cullather has argued, Agency officials 'often had little understanding of or interest in the motives of those in the Department of State, the Pentagon, and the White House who made the final decision. ${ }^{40}$ It was, then, a combination of administration desire, broader international concerns and sophisticated public relations efforts on the behalf of vested interests like United Fruit that drove the decision to intervene in Guatemala. ${ }^{41}$ By February, 1953, the New York Times was running stories describing the efforts of Guatemalan communists to seize 'outright control' and while, at this stage, some degree of separation between the communists and Arbenz was being maintained these distinctions quickly evaporated. $^{42}$

Once the spectre of communism was invoked, it became a convenient frame for analysts and officials to use in describing the threat posed by Arbenz, and went well beyond the idea of a Kremlin-controlled movement. ${ }^{43}$ Agency officials quickly latched onto this linguistic turn and began to frame their analysis accordingly. ${ }^{44}$ In briefing John Puerifoy 
before he took up his post as US Ambassador to Guatemala, CIA officials informed him that the situation there was 'adverse' to US interests and that Arbenz's link with 'communism' was the major problem. ${ }^{45}$ Similarly, by September the CIA was describing Guatemala as the 'leading base of operations for Moscow influences communism in Central America. ${ }^{, 46}$

Yet at this point it is necessary to distinguish between Allen Dulles - particularly in internal policy discussions - and the Agency. Dulles's advice in internal discussions was often far removed from the frameworks being used in internal CIA correspondence and reports. Even as covert plans developed in late-1953 and 1954, and the Eisenhower administration worked to create an international climate supportive of intervention, Dulles adopted a position of cautious pragmatism in his dealings with the White House. ${ }^{47}$ US efforts to prove links between Guatemala and the Soviet bloc by uncovering arms shipments from behind the Iron Curtain, for example, were seen as overly aggressive by DCI Dulles. This was in spite of the fact that an earlier shipment - aboard the Swedish ship, the Alfhem - had originated behind the Iron Curtain and the CIA had sought to use this to 'prove Guatemalan efforts to import clandestinely arms from behind Iron Curtain. ${ }^{48}$ Provable links between Guatemala and the Soviet bloc were fair enough, Dulles argued to the NSC in May 1954, but further shipments might 'well come from other countries than those behind the Iron Curtain.' Any subsequent publicity, he went on, should therefore 'take account of the importance of the use to which the arms were put rather than the place of origin of the shipment. ${ }^{49}$

Further evidence of Dulles's realist streak during policy discussions came in the midst of a debate on whether the Department of Justice should be allowed to bring an anti-trust ruling against the United Fruit Company in June 1954. A year earlier, it had been agreed that the action should be postponed for a year while the Attorney General sought to work with the company so that corrective steps could be taken to render the pending action obsolete, as it seemed clear that to prosecute the case at this time could have 'adverse effects on national security interests in Latin America. ${ }^{50}$ By 1954 the situation had changed and, for some officials, implementing the suit now seemed advisable. The most prominent of these - in a stance further dispelling allegations that US involvement was motivated due to high-level links between the administration and United Fruit - was Foster Dulles, who told the NSC that, given the tensions surrounding perceived US support for the company in the region, 'it might be positively advantageous to US policy in Latin America if the suit were instituted.' His brother, however, disagreed: if Washington held fire, Allen Dulles argued, their patience might well be rewarded. 'While he feared that if the Department of Justice announced the suit in the next few days the results might tend to support the position which President Arbenz had taken...this would probably not be so a month from now, by which time the situation in Guatemala would have been clarified. ${ }^{51}$

The most famous example of Dulles's pragmatism in discussions over Guatemala, however, comes from the time of the operation itself. From Washington, it quickly became apparent to the administration that if the operation was to succeed, some form of mild air support would be necessary. At a meeting at the White House, Eisenhower asked Dulles and Assistant Secretary of State, Henry Holland, whether he should authorize US air support to 
bolster the invasion. Holland said not - believing the US should 'keep [its] hands off' due to the impact this would have on Latin American opinions of the US. Dulles, on the other hand, pressed the president to say yes - telling Eisenhower that without further support the operation was doomed to failure, while a supply of aircraft would increase the chance of success to '20 per cent.' Eisenhower, in stark contrast to the events surrounding the Bay of Pigs seven years later, sided with Dulles, citing his realistic appraisal as the tipping point. 'Allen, that figure of 20 per cent was persuasive,' Eisenhower told him as he left his office. 'It showed me that you had thought this matter through realistically. ${ }^{, 52}$ Richard Bissell later wrote that Dulles's actions around the time of the invasion demonstrated his belief that 'Eisenhower would be best served if provided with the unvarnished truth about the operation's potential for failure. ${ }^{53}$ And though the results bear Bissell's assertions out, the consistent nature of Dulles's position suggests that he was neither as disinterested nor as reluctant to take part in policy discussions as has been argued.

Through 1953 and 1954, then, Allen Dulles displayed a consistent streak of pragmatism in his positions with respect to US policy toward Latin America. Moreover, this remained true even when other areas of the CIA adopted simplistic models of hysteric anticommunism and in spite of a broader administration atmosphere of strident opposition toward suspected communists. Dulles's candour and steadfast refusal to overstate a case portrays a very different side to his policymaking character than that typically in evidence in studies that focus on his role in covert operations. In the midst of the Guatemalan intervention, the New York Times identified Allen Dulles as the key figure in the administration's efforts to 'eradicate' the communist threat from Latin America. 'If somebody wants to start a revolution against the Communists in, say, Guatemala,' the paper noted, 'it is no good talking to Foster Dulles. But Allen Dulles, head of the Central Intelligence Agency, is a more active man. ${ }^{54}$ In terms of operations, the Times had a point: Dulles's CIA, after all, was specifically designed to effectively implement covert operations. When it came to policy discussions, however, this was not the case. More importantly, this raises serious questions about the relationship between Dulles's role in policy discussions and his oversight of the Agency's operations. The tone of the CIA's Cold War operations - particularly those in Latin America - do not seem to match the nature of Dulles's contributions to policy discussions. Rationality and detachment in the analytical sphere did not, in Allen Dulles's world, extend to the realms of covert action. For the historian, this suggests a more tragic outcome than that normally associated with Dulles: if it was not disinterest that characterized his role in policy discussions but was in fact realism and candour, why were these traits not transposed onto the CIA's operational plans?

\section{ALLEN DULLES AND LATIN AMERICA DURING EISENHOWER'S SECOND TERM}

During Eisenhower's second term, the CIA's lustre began to dim slightly as a series of unsuccessful operations and intelligence failures brought the Agency's role under the microscope. The Soviet launch of Sputnik in 1957, troubled CIA incursions into Indonesia, Laos and Syria, coupled with earlier problems surrounding the Suez Crisis and the Hungarian 
uprising at the end of Eisenhower's first term all conspired to sully the Agency's reputation. ${ }^{55}$ Nevertheless, Allen Dulles remained a key figure within the administration - both with respect to policy implementation, such as the U-2 spy-plane flights and operations in Laos and Indonesia, and with regard to intelligence summaries and Agency views on prevailing situations.

Although Dulles and the CIA were called upon sporadically after January 1956, it was in the wake of the Nixon trip to Caracas, Venezuela in 1958 that Dulles began to play a more prominent role. Like the Guatemalan case, Dulles became more prominent when a crisis was looming. One of the most significant features of Dulles's actions at this time was his role in assessing the causes and the impact of the protests Nixon encountered in 1958. For the first time, US officials began to consistently accept that the Latin Americans might have legitimate grievances. Dulles, moreover, was a central figure in developing this view - one that fused newly emerging views regarding nationalism with more long-standing constructs relating to international communism.

When Nixon arrived back in Washington following his traumatic experiences in Venezuela - where his motorcade had been surrounded, stoned and spat upon - he spoke candidly to the press about what was causing anti-American discontent in the region. ${ }^{56}$ The Latin Americans, Nixon stated in an address at the airport, are 'concerned, as they should be, about poverty and misery and disease which exists in so many places...they are determined to do something about it...they are moving toward economic progress. And the United States is, and should be, proud to work with them as partners. ${ }^{, 57}$ A week later, though, Nixon had reverted to reflexive anti-communism. 'Communist inspiration was evident from the similarity of placards, slogans and techniques,' Nixon told Eisenhower's cabinet. 'The Soviet Union,' John Foster Dulles quickly concurred, 'had cleverly infiltrated mass political movements in Latin America.' Allen Dulles, however, took his brother and the vice president to task. 'His agency,' he told them, 'could find no evidence that Moscow had orchestrated the Nixon incidents. ${ }^{58}$ He later provided statistical evidence, informing the NSC that of ninety nine people arrested after the protests, only twelve had links to communist groups. ${ }^{59}$ In a further report to his brother, he expressed these sentiments more clearly. 'Although undoubtedly Communist instigated,' he wrote, 'these demonstrations did give expression to a popular sense of grievances against certain phases of US policy. ${ }^{60}$

Dulles's challenge to the anti-communist assertions of Nixon and Foster Dulles came at a crucial moment. Mid-level officials in the Eisenhower administration were beginning to consistently agree that Latin American complaints against the US might be more than a result of communist incitement. And though this did not lead to any significant attempt to alter the policies that were of most concern to Latin Americans, it was a key conceptual shift in an ongoing re-evaluation of the way that the US approached the region. Indeed, it provided the impetus that officials and advisors like Thomas Mann, Milton Eisenhower, Roy Rubottom and Douglas Dillon used to push the idea that the US should utilise intelligent - and high profile - economic loans to alleviate inter-American tensions. While this did not mark any renunciation of the administration's previous economic approach, it did mark a change in 
inter-American affairs. ${ }^{61}$ Dulles added to this trend with his backing for a mission, and subsequent report, by Milton Eisenhower shortly after Nixon's return. With fears about further protests leading to suggestions that the trip be cancelled, Dulles - this time in tandem with his brother - provided the momentum to ensure that the trip took place despite the likelihood of anti-American protests. The report that emerged, moreover, was a key document in bringing about significant shifts in the way the administration viewed the region. ${ }^{62}$

Further examinations of communist activities in the region took their lead from Dulles and downplayed fears of a rapidly emerging communist threat in the region. ${ }^{63}$ Although CIA reports suggested that both Moscow and Beijing were looking to expand their interests in the area, the disparate nature of Latin American socialist movements made their success far from certain. Thus, while the danger of these groups forming a pro-Soviet neutralist bloc certainly existed, the nature of Latin American socialism meant that these groups remained uncommitted. 'In studying socialism in Latin America,' a CIA appraisal noted, 'it should be understood that it is not a uniform movement bound by a coherent ideology and a monolithic discipline as the International Communist Movement. ${ }^{64}$

Again, it is important to note that Allen Dulles remained firmly committed to the fight against communism; his interjections, as they had during the Guatemalan episode, came when other officials were overstating the case. Equally, there are signs in the post-1958 period of Dulles beginning to become more vocal in his advocacy of CIA operations in the region. H.W. Brands has argued that this was a result of a shift in internal dynamics following Foster Dulles's death from cancer in April 1959. ${ }^{65}$ Though this argument carries obvious weight, it is also clear that this was beginning at a much earlier stage. Following the Nixon trip, in fact, DCI Dulles told the NSC: 'we may at long last get the necessary support of these [Latin American] governments against the Communist. We are all ready to go if we can get such support. ${ }^{66}$ Thus while Allen Dulles did become a more prominent voice in the administration, this was not just because of the loss of his brother; other factors, such as the need to improve the CIA's track record and a growing frustration at developments in the Cold War, also drove this shift. Yet even then, Dulles remained pragmatic and even-handed in his assessments of emerging threats. When the administration became concerned about a possible communist threat in Mexico in early-1959, Dulles wrote Eisenhower and informed him that this was not as simple as the US opposing Soviet directed communism in Central America. 'The Communist threat in Mexico,' Dulles wrote, 'stems from two main elements: The Soviet and satellite diplomatic missions and native Marxism, coupled with extreme nationalism. ${ }^{, 67}$

The final examples of Dulles's actions come with the case-study of Cuba, which, although problematic for the US throughout the period after 1956, became a major concern following Fidel Castro's overthrow of Fulgencio Batista on New Year's Day 1959. ${ }^{68}$ Prior to this, the CIA's performance had been far from spectacular; best estimates as to what was happening and predictions about the immediate future had proven erratic. At a meeting at the State Department just a few hours before Castro took power - a meeting which included two 
participants from the Agency - much of the talk was focused upon determining the US view of Castro and previous American efforts to foster a 'third way' between Castro and Batista. It was only as the meeting was breaking up that it was suggested that 'Batista would leave the country within 48 hours' - a proposal, moreover, that came from the US Ambassador in Havana and the Joint Chiefs of Staff, rather than the CIA. ${ }^{69}$

Once Castro's victory was assured, Allen Dulles again became a more prominent voice in internal discussions as US efforts turned to analysing the new regime and trying to predict its future course. Throughout 1958 and 1959, Dulles maintained a strong line on Cuba - eschewing the temptation to paint Castro as a communist and insisting that, while key advisors like Che Guevara and Raul Castro might be communists, Castro was not. After the revolution, Dulles even testified sympathetically to Congress about emerging reports of the Castro regime executing its political opponents; it made sense, Dulles mused, 'to kill your enemies. ${ }^{, 70}$ Nevertheless, both Dulles and Agency analysts were concerned about the new regime in Cuba because of how Castro might destabilise the region. Dulles told the NSC that Cuba posed the most serious problem in the region, while Castro seemed to view himself as a 'man on horseback, destined not only to liberate Cuba but to liberate all other dictatorships in Latin America.' In conclusion, Dulles advocated a cautionary, if firm and paternalistic, stance toward Castro. 'The new Cuban officials,' he stated, 'had to be treated more or less like children. They had to be led rather than rebuffed. If they were rebuffed, like children, they were capable of doing almost anything. ${ }^{71}$

As US views of Castro's regime began to take the view that his agenda was much more radical than Washington would like - inspired predominantly by high-profile nationalism, an abundant desire to be free of US influence and, just as troublingly, to aggressively oppose right-wing dictatorships in the region - the Eisenhower administration began to adopt a position of strong opposition to the government in Havana. At this stage, neither leading administration officials nor the CIA believed Castro to be communist. In fact, Cuban communists visiting a Soviet conference in 1959 were warned, according to an Agency record of the conference, that Castro "may "go to the right" and betray [the] revolution'; subsequent Agency efforts to brief Castro about the conference, moreover, sparked a frank exchange with the Cuban leader about the threat that communism posed in Cuba. $^{72}$ Partly as a result of Castro's apparent anti-communism, the Eisenhower administration and the CIA faced a difficult time in understanding Cuban anti-Americanism and the reasons that the government in Havana wanted to chart an independent course. ${ }^{73}$ This was expressed most stridently by Eisenhower himself, who told a reporter in October, 1959: 'You would think they would want good relationships. I don't know exactly what the difficulty is. ${ }^{74}$

Like in Guatemala, the decision to consider a move against Castro came predominantly from the White House, after which Agency and State Department planners moved to begin designing an operation. Interestingly, the CIA's first plan - presented to the president by Dulles in early 1960 - was rejected for not being ambitious enough and failing to 'move against Castro in a positive and aggressive way which went beyond pure 
harassment. ${ }^{75}$ Shortly after, covert planning - as well as diplomatic and political efforts against Castro began to accelerate. For the purposes of this article, Allen Dulles's most important role in this phase was in providing pragmatic analysis on the impact that Castro was having on the situation in the Caribbean and the affect that this was having on US interests in the region. ${ }^{76}$ In particular, the way that the developing animosity on behalf of Castro and Venezuelan leader Romulo Betancourt toward the reviled Dominican dictator Rafael Trujillo was threatening to boil over and destabilise the area. ${ }^{77}$ With Castro and Betancourt conspiring to oust Trujillo, US officials were faced with an obvious quandary as their position toward Cuba hardened: how could they mobilise Latin American - and international - support against Castro if they allowed Trujillo to remain in office ${ }^{78}$

At first, neither Eisenhower nor his new secretary of state, Christian Herter, wanted to move against Trujillo. But the gradual realisation that opposing Trujillo was necessary if the US wanted to attain support against Castro began to tip the balance. By the spring of 1960 , the Eisenhower administration had come to accept that Trujillo would have to leave office; moreover, they were so eager for Betancourt's support against Castro that a shift in the dynamics in the Caribbean seemed desirable. ${ }^{79}$ Though this shift had already begun to take place, it was again given added weight and impetus by the support of Allen Dulles. The record of an NSC meeting in July, 1960, noted: 'Mr Dulles stated that he believes, and the intelligence community agrees, that the problem of Trujillo must be settled before the problem of Castro can be dealt with, even though Castro is the greater threat. ${ }^{, 80}$ At the same time that his agency was planning a speculative and dangerous covert operation against Castro, therefore, Allen Dulles was still doing what he had done for the majority of Eisenhower's presidency: provide the president with candid and pragmatic advice about the situation in Latin America. The great mystery, however, remains why he was unable to adopt the same principles to the Agency's operations.

\section{CONCLUSION}

In April 1961, just a few months after John F. Kennedy assumed the presidency, a brigade of US-trained Cuban exiles waded ashore at the Bay of Pigs in Cuba in an attempt to launch an insurgency that would ultimately overthrow Fidel Castro. The subsequent failure of the operation - partly because the Cuban army knew the insurgents were coming, partly because of poor planning on the US side, and partly because Kennedy refused to sanction the full range of air support missions recommended by the CIA - was a high-profile disaster for the new president (albeit one that carried more impact abroad than at home). During the ensuing fall-out, which saw Kennedy's approval ratings actually go up, Dulles's tenure at the CIA was brought to an ignominious end. ${ }^{81}$ This incident, coupled with the high-profile nature of US involvement in Guatemala, has imposed a narrative of covert operations, fervent anticommunism and, ultimately, failure onto examinations of Allen Dulles's role in US-Latin American relations. Dulles himself recognised this and, in the 1960s, drafted several attempts of a rebuttal to critics who blamed him and the CIA for the failed ousting of Castro. ${ }^{82}$ Piero Gleijeses has noted, however, that the failure over the Bay of Pigs was down to a lack of communication between the Agency and the Kennedy White House: when push came to 
shove, Gleijeses writes, each made assumptions about the other's behavior that ultimately proved inaccurate. ${ }^{83}$ 'We felt that when the chips were down - when the crisis arose in reality, any action required for success would be authorized rather than permit the enterprise to fail,' Dulles later noted. ${ }^{84}$

Despite Dulles's disavowal, we can see in the Bay of Pigs the tragedy that ultimately lies at the centre of any study of his career as DCI. Had he been as rational in decisions over operations as he was in policy discussions on Latin America then his reputation might not be so tarnished. ${ }^{85}$ Clearly capable, and often more rational than many of his contemporaries, Allen Dulles was an inherently flawed character when it came to operational responsibility. This dichotomy, moreover, is made more sobering when one considers that it was not disinterest in the policy and analysis sphere that fed these problems, but a climate at the CIA that was almost entirely of his own making. Such conclusions make a report that Time published shortly after the Bay of Pigs striking in its discussion of whether intelligence agencies should conduct operations. 'Last week,' the report stated, the 'CIA was back in the news in a big way - and will probably stay there for some time, while a basic question that has been long and heatedly debated is argued out. Should any intelligence-gathering organization also have an operations responsibility? ${ }^{86}$ In the case of Allen Dulles's involvement in the Eisenhower administration's policy toward Latin America, it seems clear that the answer is 'no'.

For his part, Dulles remained able to surprise with his realism and candour until he left his position with the Agency in November 1961. After a meeting with British officials in October of that year - in which Dulles had conveyed American dissatisfaction with Washington's European partners and raised the possibility of a retreat to 'isolationism' - an official in the British Ministry of Defence sent a summary to the Prime Minister's office, noting: 'I must admit that the vehemence and somewhat sweeping nature of Dulles' remarks took me by surprise. ${ }^{87}$ Beyond the ramifications that Dulles's role has for the relationship between policy-making and Agency operations, however, this reappraisal of Dulles's role opens up obvious avenues to re-examine his participation in other areas of policy. With respect to Latin America, the consistently pragmatic nature of Dulles's approach complicates previous understandings of his role in the administration, as well as posing new questions about the exact nature of the relationship between him and his brother when it came to policy-making discussions. Given the bureaucratic clout that Dulles had within the administration - and given the extent to which Eisenhower took his suggestions onboard the recurrent nature of his pragmatic approach to Latin American policy discussions carried obvious weight. And though Dulles's motivation in taking this approach is not always clear, the implications that this has for understanding the administration's policy-making structures are much more evident. Extending this appraisal to other areas of policy, for example, may well shed important new light on the role of the CIA in the 1950s. Similarly, examining Allen Dulles's role in more detail may start to divert scholarly attention away from the EisenhowerFoster Dulles nexus that has dominated examinations of who determined US foreign policy in this era and bring other officials and agencies into the fold. ${ }^{88}$ Allen Dulles, as the present article has suggested, was not just a covert operations enthusiast; understanding how far this 
pragmatic facet to his character extended into other avenues offers intriguing possibilities for intelligence scholars.

\footnotetext{
${ }^{1}$ I am enormously grateful to Richard Immerman, Kaeten Mistry, Giles Scott-Smith, and the anonymous reviewer for INS for their comments on earlier versions of this article.

${ }^{2}$ Greg Grandin, Empire's Workshop: Latin America, the United States, and the Rise of the New Imperialism (New York: Metropolitan Books, 2006) p 43-4

${ }^{3}$ On the CIA in this era, see Peter Grose, Gentleman Spy: The Life of Allen Dulles (Boston, Masschusetts: Houghton Mifflin, 1994); Michael A. Turner, Why Secret Intelligence Fails (Dulles, Virginia: Potomac Books, 2005); Rhodri Jeffreys-Jones, The CIA and American Democracy Third Edition (New Haven: Yale University Press, 2003); For a predictably partisan assessment of the Dulles era, 'A Look Back...Allen Dulles Becomes DCI,' Central Intelligence Agency Website, https://www.cia.gov/news-information/featured-storyarchive/allen-dulles-becomes-dci.html Accessed on December 20 2010; for a rebuttal of the notion of this being a 'golden age', Tim Weiner, 'How to Make a Spy,' Foreign Affairs, August 15 2007; For cultural representations of the CIA in the 1950s, Robert Littell, The Company: A Novel of the CIA (London: Pan Books, 2003); and the 2007 film The Good Shepherd. Oliver Stone's 1991 film JFK also highlighted the prominence of the CIA in the period leading up to the 1960s.
}

${ }^{4}$ Kenneth Osgood, Total Cold War: Eisenhower's Secret Propaganda Battle at Home and Abroad (Lawrence, Kansas: Kansas University Press, 2006) pp 46-153; Robert Bowie and Richard Immerman, Waging Peace: How Eisenhower Shaped an Enduring Cold War Strategy (New York: Oxford University Press, 1998); John Prados, "The Central Intelligence Agency and the Face of Decolonization under the Eisenhower Administration," in Kathryn Statler and Andrew Johns (eds), The Eisenhower Administration, the Third World, and the Globalization of the Cold War (Lanham, Maryland: Rowman \& Littlefield, 2006) pp 27-47; John Lewis Gaddis, Strategies of Containment: A Critical Appraisal of American National Security Policy during the Cold War Revised Edition (New York: Oxford University Press, 2005) pp 155-9

5 “Espionage: The Hearty Professional,” Time, 7 February 1969

${ }^{6}$ For a description of the policymaking bureaucracy under Eisenhower see: Anna Kasten Nelson, "The 'Top of Policy Hill': President Eisenhower and the National Security Council,” Diplomatic History Volume 7 (Fall 1983) pp 307-26

${ }^{7}$ There are some exceptions, but generally this has remained accurate. See: Stephen Rabe, Eisenhower: The Foreign Policy of Anticommunism and Latin America (Chapel Hill: University of North Carolina Press, 1988); James Siekmeier, Aid, Nationalism, and Inter-American Relations: Bolivia, Guatemala, and the United States, 1953-1961 (New York: Edwin Mellen Press, 1999). Works that specifically deal with the CIA's role in Guatemala are: Nick Cullather, Secret History: The CIA's Classified Account of its Operations in Guatemala, 1952-1954 (Stanford: Stanford University Press, 1999); Richard Immerman, The CIA in Guatemala (Austin, Texas: University of Texas Press, 1982)

${ }^{8}$ Allen Dulles, The Craft of Intelligence (London: Weidenfield and Nicholson, 1963)

${ }^{9}$ National Security Act of 1947. Taken from: http://intelligence.senate.gov/nsaact1947.pdf Accessed on 25 September 2009

${ }^{10}$ Allen Dulles (eds), Great True Spy Stories (New York: Harper \& Row, 1968) p xi 
${ }^{11}$ Peter Grose, Gentleman Spy: The Life of Allen Dulles (Boston, Masschusetts: Houghton Mifflin, 1994) p 341; H.W. Brands, Cold Warriors: Eisenhower's Generation and American Foreign Policy (New York: Columbia University Press, 1988) p 55-6; Richard Immerman, "Intelligence and Strategy: Historicizing Psychology, Policy, and Politics" Diplomatic History Volume 32, No 1 (January 2008) p 10-11; James Srodes, Allen Dulles: Master of Spies (Washington D.C.: Regnery Publishing, 1999) p 4-5; Hugh Wilford, The Mighty Wurlitzer: How the CIA Played America (Cambridge, Massachusetts: Harvard University Press, 2008) p 47-8; Tim Weiner, Legacy of Ashes: The History of the CIA (London: Penguin Books, 2008) p 79

${ }^{12}$ He wasn’t and, as a result, Dulles owed Humphrey \$3. See: Letter from George Humphrey to Allen Dulles, September 12 1957; Letter from Allen Dulles to George Humphrey, September 29 1957, Box 32, Allen Dulles Papers, Seeley G. Mudd Library, Princeton, New Jersey (hereafter SML)

${ }^{13}$ Peter Boyle, Eisenhower: Profiles in Power (Harlow, UK: Pearson Education Limited, 2005) p 28

${ }^{14}$ Greg Grandin, The Blood of Guatemala: A History of Race and Nation (Durham, North Carolina: Duke University Press, 2000); idem, The Last Colonial Massacre: Latin America in the Cold War (Chicago: Chicago University Press, 2004); Robert McMahon, “"The Point of No Return': The Eisenhower Administration and Indonesia, 1953-1960" in Kathryn Statler and Andrew Johns (eds), The Eisenhower Administration, the Third World, and the Globalization of the Cold War (2006) pp 75-101

${ }^{15}$ John Ranelagh, The Agency: The Rise \& Decline of the CIA (Cambridge, UK: Sceptre, 1987) pp 72-8; Leonard Mosley, Dulles: A Biography of Eleanor, Allen, and John Foster Dulles and their Family Network (New York: The Dial Press, 1978) pp 268-73; H.W. Brands, Cold Warriors (1988) pp 48-71; on Congressional oversight and the CIA, Loch K. Johnson, America's Secret Power: The CIA in a Democratic Society (New York: Oxford University Press, 1991); idem, "Covert Action and Accountability: Decision-Making for America's Secret Foreign Policy,” International Studies Quarterly Volume 33 (1989) pp 81-109; idem, "Congressional Supervision of America's Secret Agencies: The Experience and Legacy of the Church Committee," Public Administration Review Volume 64, Issue 1 (January 2004) pp 3-14

${ }^{16}$ Kenneth Osgood, Total Cold War (2006) pp 46-153; Robert Bowie and Richard Immerman, Waging Peace (1998)

${ }^{17}$ Marc Selverstone, Constructing the Monolith: The United States, Great Britain, and International Communism, 1945-1950 (Cambridge, Massachusetts: Harvard University Press, 2009) pp 218-22

18 "A Current Intelligence Appreciation of Soviet Policy," Lecture by Head of the CIA Allen Dulles at the National War College, 30 April 1954. Taken from: http://www.princeton.edu/ mudd/finding_aids/MC019.09/Reports_English 19431977 and undated/19540430_0000034856.pdf Accessed on 4 August 2009

${ }^{19}$ William Taubman, Khrushchev: The Man, His Era (New York: The Free Press, 2003) Ch. 13; Burton Kaufman, Trade \& Aid: Eisenhower's Foreign Economic Policy, 1953-1961 (Baltimore: John Hopkins University Press, 1982) Ch. 4; Odd Arne Westad, The Global Cold War: Third World Interventions and the Making of Our Times (Cambridge, UK: Cambridge University Press, 2005) pp 27-38, 66-72

20 "Reasons for the Impact of Soviet Orbit's Military, Economic, Cultural Drive in the Middle East, South, and Southeast Asia," Report by Allen Dulles, undated 1956. Taken from: http://www.princeton.edu/ mudd/finding_aids/MC019.09/Reports_English_19431977_and_undated/19560301_0000075280.pdf Accessed on 4 August 2009

${ }^{21}$ Memorandum of Discussion at the $273^{\text {rd }}$ Meeting of the National Security Council, 18 January 1956, FRUS 1955-1957 Volume X pp 64-8

${ }^{22}$ Memorandum of Discussion at the $359^{\text {th }}$ Meeting of the National Security Council, 20 March 1958, FRUS 1958-1960 Volume III pp 51-6, quote on p 54; on Indonesia: Robert McMahon, “"The Point of No Return': The Eisenhower Administration and Indonesia, 1953-1960" in Kathryn Statler and Andrew Johns (eds), The Eisenhower Administration, the Third World, and the Globalization of the Cold War (2006) pp 75-101; Bradley Simpson, Economists with Guns: Authoritarian Development and US-Indonesian Relations, 1960-1968 (Stanford, California: Stanford University Press, 2008) p 32 
${ }^{23}$ Letter from President Eisenhower to CIA Director Allen Dulles, December 30 1953, Box 24, Allen Dulles Papers, SML

${ }^{24}$ Letter from Allen Dulles to President Eisenhower, January 15 1957, Box 24, Allen Dulles Papers, SML

${ }^{25}$ Letter from President Eisenhower to Allen Dulles, December 20 1960; Letter from Allen Dulles to Eisenhower, January 18 1961, Box 24, Allen Dulles Papers, SML

${ }^{26}$ Record of Conversation between British Secretary of State and CIA Director Allen Dulles, 2 February 1956, FO 371/123446, UK National Archives, Kew, London; for an accurate appraisal of the situation in Vietnam in the 1950s, Mark Bradley, Vietnam at War (New York: Oxford University Press, 2009) pp 77-101

${ }^{27}$ Memorandum of Discussion at the $132^{\text {nd }}$ NSC Meeting, 18 February 1953, Box No 4, NSC Series, Ann Whitman File, Eisenhower Library

${ }^{28}$ James Siekmeier, Aid, Nationalism and Inter-American Relations (New York: Edwin Mellen Press, 1999)

${ }^{29}$ Memorandum of Discussion at the $132^{\text {nd }}$ NSC Meeting, 18 February 1953, Box No 4, NSC Series, Ann Whitman File, Eisenhower Library

${ }^{30}$ Richard Immerman, though, notes that this use of intelligence was not solely to do with CIA - other agencies, such as the State Department, the Pentagon, and the United States Information Agency, also contributed heavily to intelligence gathering and utilisation. Richard Immerman, "Intelligence and Strategy" (2008) p10-11; Nicholas Cull, The Cold War and the United States Information Agency: American Propaganda and Public Diplomacy, 1945-1989 (Cambridge, UK: Cambridge University Press, 2008) pp 81-134; John Lewis Gaddis, Strategies of Containment (2005) pp 152-9; Scott Lucas, Freedom's War (1999) Ch. 10; Philip Taubman, Secret Empire: Eisenhower, the CIA, and the Hidden Story of America's Space Espionage (New York: Simon \& Schuster, 2004)

${ }^{31}$ Memorandum of Discussion at the $137^{\text {th }}$ Meeting of the National Security Council, 18 March 1953, FRUS 1952-1954 Volume IV The American Republics pp 2-6

${ }^{32}$ Statement of Policy by the National Security Council - NSC 144/1, 18 March 1953, FRUS 1952-1954 Volume IV pp 6-10; Stephen Rabe, Eisenhower (1988) Ch. 2

${ }^{33}$ See: Memorandum from Under Secretary of State Walter Bedell Smith to the Executive Secretary of the NSC James Lay, "First Progress Report on NSC 144/1", 23 July 1953; Memorandum from Under Secretary of State Walter Bedell Smith to the Executive Secretary of the NSC James Lay, "Second Progress Report on NSC 144/1", 20 November 1953; Memorandum from Under Secretary of State Walter Bedell Smith to the Executive Secretary of the NSC James Lay, "Third Progress Report on NSC 144/1", 25 May 1954 - all from FRUS 19521954 Volume IV pp 11-65

${ }^{34}$ Piero Gleijses, Shattered Hope: The Guatemalan Revolution and the United States, 1944-1954 (Princeton, New Jersey: Princeton University Press, 1992)

${ }^{35}$ Nick Cullather, Secret History: The CIA's Classified Account of its Operations in Guatemala, 1952-1954 (Stanford: Stanford University Press, 1999) pp 7-37

${ }^{36}$ Memorandum of Discussion at the $132^{\text {nd }}$ NSC Meeting, 18 February 1953, Box No 4, NSC Series, Ann Whitman File, Eisenhower Library

${ }^{37}$ Memorandum for the Record, by the Director of Central Intelligence Allen Dulles, 8 March 1953, Foreign Relations of the United States 1952-1954 Guatemala (Washington: United States Government Printing Office, 2003) p 79

38 "Probable Developments in Guatemala", National Intelligence Estimate, 19 May 1953, FRUS 1952-1954 Volume IV pp 1061-3 
${ }^{39}$ Jim Handy, “'The Most Precious Fruit of the Revolution': The Guatemalan Agrarian Reform, 1952-54", Hispanic American Historical Review Volume 68, No. 4 (1988) pp 675-705. Max Holland, "Private Sources of US Foreign Policy: William Pawley and the 1954 Coup d'Etat in Guatemala", Journal of Cold War Studies Volume 7, No. 4 (Fall 2005) pp 36-73; Kenneth Osgood, Total Cold War (2006) p 146-7

${ }^{40}$ Nick Cullather, Secret History (1999) p 8

${ }^{41}$ Richard Immerman, The CIA in Guatemala (1982) pp 109-18; Blanche Wiesen-Cook, The Declassified Eisenhower: A Divided Legacy (Garden City, New York: Doubleday, 1981)

${ }^{42}$ Sydney Gruson, "Guatemalan Reds Seek Full Power," New York Times, 23 February 1953 p 4; "The Guatemalan Picture," New York Times, 24 February 1953, p 24; Sydney Gruson, "How Communists Won Control of Guatemala," New York Times, 1 March 1953, p E6

${ }^{43}$ James Siekmeier, "Latin American Economic Nationalism and United States-Latin American Relations, 1945-1961," The Latin Americanist Volume 52, Issue 3 (October 2008) pp 59-76

${ }^{44}$ David Ryan, US Foreign Policy in World History (2000) pp 149-54

${ }^{45}$ Author's name not declassified, Memorandum for the Record, Briefing of Ambassador John Peurifoy re. Guatemala, 1 September 1953, FRUS 1952-1954 Guatemala Doc No. 45

${ }^{46}$ Memorandum for the Record by J.C. King, 11 September 1953, FRUS 1952-1954 Guatemala Doc No. 51

${ }^{47}$ Stephen Rabe, Eisenhower (1988) Ch. 3; Piero Gleijeses, Shattered Hope (1992); Richard Immerman, The CIA in Guatemala (1982) Ch. 6

${ }^{48}$ Telegram from the Central Intelligence Agency to the CIA Station in [place not declassified], 16May 1954, FRUS 1952-1954 Guatemala Doc no. 152

${ }^{49}$ Memorandum of Discussion at the $199^{\text {th }}$ Meeting of the National Security Council, 27 May 1954, FRUS 1952-1954 Volume IV Latin American Republics pp 1131-35

${ }^{50}$ NSC Action No. 805 Regarding Anti-Trust Proceedings in Latin America, 4 June 1953, NSC 152/3 US Economic Defense Policy (2), Box No 5, NSC Series - Policy Paper Sub-series, Eisenhower Library

${ }^{51}$ Memorandum of Discussion at the $202^{\text {nd }}$ Meeting of the National Security Council, 17 June 1954, FRUS 1952-1954 Volume IV The American Republics pp 224-6

${ }^{52}$ Dwight D. Eisenhower, Mandate for Change (1963) p 425-6; Nick Cullather, Secret History (1999) p 98; Memorandum by the Director of Central Intelligence Allen Dulles to President Eisenhower, 20 June 1954, FRUS 1952-1954 Volume IV The American Republics pp 1174-6

${ }^{53}$ Richard Bissell, Jonathan Lewis and Frances Pudlo, Reflections of a Cold Warriors: From Yalta to the Bay of Pigs (New Haven, Connecticut: Yale University Press, 1996) p 85

${ }^{54}$ James Reston, "With the Dulles Brothers in Darkest Guatemala,” New York Times, 20 June 1954, p E8

55 John Ranelagh, The Agency (1988) pp 270-348; John Prados, "The Central Intelligence Agency and the Face of Decolonization under the Eisenhower Administration," (2006)

${ }^{56}$ On the Nixon trip, see: Alan McPherson, Yankee No!: Anti-Americanism in US-Latin American Relations (Cambridge, Massachusetts: Harvard University Press, 2003) Ch. 1

${ }^{57}$ Address by Vice President Nixon at the Airport in Washington DC, May 15, Department of State Bulletin Volume 38, 9 June 1958 pp 950-52 
${ }^{58}$ Minutes of Cabinet Meeting, 16 May 1958, FRUS 1958-1960 Volume Vp 238-9; Stephen Rabe, "The Caribbean Triangle: Betancourt, Castro, and Trujillo and US Foreign Policy, 1958-1963”, Diplomatic History Volume 20, No 1 (Winter 1996) p 57

${ }^{59}$ Memorandum of Discussion at the $366^{\text {th }}$ Meeting of the National Security Council, 22 May 1958, Box No 10, NSC Series, Whitman File, Eisenhower Library

${ }^{60}$ Memorandum from the Director of Central Intelligence Allen Dulles to the Secretary of State John Foster Dulles, 27 May 1958, FRUS 1958-1960 Volume V pp 252-5

${ }^{61}$ Milton Eisenhower, The Wine is Bitter: US-Latin American Relations (New York: Doubleday and Inc, 1963); Lars Schoultz, Beneath the United States: A History of US Policy Toward Latin America (Cambridge, Massachusetts: Harvard University Press, 1998) pp 351-5; Michael Adamson, “"The Most Important Single Aspect of our Foreign Policy'?: The Eisenhower Administration, Foreign Aid, and the Third World," in Kathryn Statler and Andrew Johns (eds), The Eisenhower Administration, the Third World and the Globalization of the Cold War (2006) pp 47-75

${ }^{62}$ Memorandum from the Director of Central Intelligence Allen Dulles to Secretary of State Dulles, May 27 1958; Memorandum for the Record of a Meeting in the White House between President Eisenhower, Secretary Dulles, Under Secretary Christian Herter and Assistant Secretary of State Roy Rubottom, June 2 1958, FRUS 1958-1960 Volume V pp 252-6; Memorandum of a Conversation, Department of State, June 24 1958, FRUS 1958-1960 Volume V pp 260-3; Milton Eisenhower, The Wine is Bitter (1963); Milton Eisenhower, "Report to the President: US-Latin American Relations", December 27 1958, Box No 7, Milton Eisenhower Papers, Eisenhower Library

${ }^{63}$ See: Stephen Clissold (eds), Soviet Relations with Latin America, 1918-1968: A Documentary Survey (London: Oxford University Press, 1970)

${ }^{64}$ CIA Report, "Principle Aspects of Socialism in Latin America," October 1958; CPSU Coordination of International Communist Movement: Implement, 25 July 1958 (est. date); Letters from General Cabell of the CIA to General Andrew Goodpaster and Vice President Richard Nixon, 11 April 1959. Taken from: http://www.foia.cia.gov Accessed on 20 August 2009

${ }^{65}$ H.W. Brands, Cold Warriors (1988) p 56

${ }^{66}$ Memorandum of Discussion at the $366^{\text {th }}$ National Security Council Meeting, 22 May 1958, FRUS 1958-1960 Volume V pp 239-46

${ }^{67}$ Letter from Director of Central Intelligence Allen Dulles to President Eisenhower, 12 February 1959. Taken From: http//:www.foia.cia.gov Accessed on 27 September 2009

${ }^{68}$ Thomas Paterson, Contesting Castro: The United States and the Triumph of the Cuban Revolution (New York: Oxford University Press, 1994); Lars Schoultz, That Infernal Little Cuban Republic: The United States and the Cuban Revolution (Chapel Hill: University of North Carolina Press, 2009) Chs. 3 \& 4; Cole Blasier, The Hovering Giant: US Responses to Revolutionary Change in Latin America 1910-1985 (Pittsburgh: University of Pittsburgh Press, 1985) Revised Edition, pp 178-211

${ }^{69}$ Although the Agency's representatives did eventually concur with the assessment: Memorandum of a Conversation, Secretary of State Christian Herter's office, Department of State, 31 December 1958, FRUS 1958-1960 Cuba Volume VI pp 323-9

${ }^{70}$ Dulles's views and quotes outlined in: Stephen Rabe, Eisenhower (1988) p 122-3; Stephen Ambrose, Eisenhower: Soldier and President (New York: Touchstone, 1990) p 498-9; Alan McPherson, Yankee No! (2003) p 48-9

${ }^{71}$ Memorandum of Discussion at the $396{ }^{\text {th }}$ Meeting of the National Security Council, 12 February 1959, FRUS 1958-1960 Cuba Volume VI p 397-8; Notes on NSC Briefing by Allen Dulles prepared by Walter Elder, 12 February 1959. Taken From: http://www.foia.cia.gov Accessed on 28 September 2009; on paternalism in USLatin American relations, Michael Hunt, Ideology in US Foreign Policy (1987) Ch. 3 
${ }^{72}$ Briefing Paper on CPSU conference and subsequent CIA Briefing to Fidel Castro, 8 July 1959. Taken From: http://www.foia.cia.gov Accessed on 28 September 2009

${ }^{73}$ Alan McPherson, Yankee No! (2003) Ch. 2; idem, “The Limits of Populist Diplomacy: Fidel Castro's April 1959 Trip to North America,” Diplomacy and Statecraft Volume 18, No. 1 (March 2007)

${ }^{74}$ Press Conference by President Eisenhower, 28 October1959. Taken From: http://www.presidency.ucsb.edu/ws/index.php?pid=11569\&st=cuba\&st1 Accessed on 5 March 2008

${ }^{75}$ Information and quote taken from: Piero Gleijeses, "Ships in the Night: The CIA, the White House and the Bay of Pigs," Journal of Latin American Studies Volume 27, No 1 (February 1995) p 3-4

${ }^{76}$ Stephen Rabe, “The Caribbean Triangle” (1996)

${ }^{77}$ Michael R. Hall, Sugar and Power in the Dominican Republic: Eisenhower, Kennedy and the Trujillos (Westport, Connecticut: Greenwood Press, 2000)

${ }^{78}$ On emerging Cuban and Venezuelan moves against Trujillo: Notes on NSC Briefing, 8 July 1959. Taken From: http://www.foia.cia.gov Accessed on 29 September 2009

${ }^{79}$ Stephen Rabe, "The Caribbean Triangle" (1996) pp 62-70; for details on Dulles's pragmatism in the West Indies: Jason Parker, Brother's Keeper: The United States, Race, and Empire in the British Caribbean, 19371962 (New York: Oxford University Press, 2008) p 133

${ }^{80}$ Memorandum of Discussion at the $450^{\text {th }}$ Meeting of the National Security Council, 7 July 1960 , Box No 12 , NSC Series, Ann Whitman File, Eisenhower Library

${ }^{81}$ Lawrence Freedman, Kennedy's Wars: Berlin, Laos, Cuba and Vietnam (New York: Oxford University Press, 2000) pp 145-8

${ }^{82}$ Lucien S. Vandenbroucke, "The 'Confessions' of Allen Dulles: New Evidence on the Bay of Pigs," Diplomatic History Volume 8, Issue 4 (October 1984) pp 365-76; also see, Richard M. Bissell, "Response to Lucien S. Vandenbroucke," Diplomatic History Volume 8, Issue 4 (October 1984) pp 377-82; Drafts of Dulles's response, which remained unpublished, can be found in Boxes 62 and 63, Allen Dulles Papers, SML

${ }^{83}$ Piero Gleijeses, "Ships in the Night" (1995) p 40-1

${ }^{84}$ Quoted in: John Ranelagh, The Agency: The Rise \& Decline of the CIA (London: Spectre, 1987) p 372

${ }^{85}$ On the Bay of Pigs: Richard Bissell, Confessions of a Cold Warrior (1996) pp 152-204; Peter Kornbluh (eds), Bay of Pigs Declassified: The Secret CIA Report on the Invasion of Cuba (New York: The New Press, 1998)

86 "Nation: When it's in the News its in Trouble," Time, 28 April 1961

${ }^{87}$ Letter from Ministry of Defence to the Prime Minister's Office, 2 October 1961, PREM 11/3614, UK National Archives, Kew, London

${ }^{88}$ On Eisenhower revisionism: Stephen Rabe, "Eisenhower Revisionism: The Scholarly Debate" in Michael Hogan (eds), American in the World: The Historiography of American Foreign Relations since 1941 (Cambridge: Cambridge University Press, 1995) pp 300-325; Robert Bowie and Richard Immerman, Waging Peace (1998); Chris Tudda, The Truth is our Weapon: The Rhetorical Diplomacy of Dwight D. Eisenhower and John Foster Dulles (Baton Rouge: Louisiana State University Press, 2006) pp 1-5 